\title{
Piecing together the FTO jigsaw
}

\author{
Timothy M Frayling* and Ken Ong ${ }^{2,3}$
}

\section{Abstract \\ Two recent studies of the FTO gene provide more information on how it affects body mass index.}

It is nearly 4 years since genome-wide association studies identified common variants in the human fat mass and obesity associated (FTO) gene to be associated with normal variation in body mass index (BMI) in several adult population studies [1]. The finding was the first robust identification of a common variant with BMI and obesity, and the 'fat gene' story made scientific and media headlines.

The same studies in human populations established that the effect on BMI was driven entirely through adiposity, as opposed to skeletal or lean tissue mass, and that the effect on BMI was not present at birth, was fully present by the age of 7 years, and seemed to be stable throughout adulthood [1]. But to use the analogy of a jigsaw puzzle, these observations represented 'sky' pieces - good to find but of limited use in finding the next piece. The next move was hindered by the fact that the gene had no obvious known role in metabolism, appetite control, or activity levels and the function of the protein was poorly characterized. Scientists could not even be sure they had the right gene - genome-wide association studies identify DNA variants, not genes, that are associated with traits and, although the associated variants are in intron 1 of FTO, they are close to the 5' end of the gene encoding the retinitis pigmentosa GTPase regulatorinteracting protein 1-like protein (RPGRIP1L). If a variant is 'in' the FTO gene, it does not necessarily mean that it 'acts through' the FTO gene.

A few more pieces to the puzzle were found in the first year following the identification of the FTO association with BMI. Studies described the FTO protein as a 2-oxoglutarate-dependent enzyme that localizes to the

\footnotetext{
*Correspondance: tim.frayling@pms.ac.uk

'Peninsula College of Medicine and Dentistry, University of Exeter, Magdalen Road, Exeter EX1 2LU, UK

Full list of author information is available at the end of the article
}

nucleus, found that it is widely expressed but especially so in the hypothalamus (in humans and mice), and that expression in the arcuate nucleus of the hypothalamus (the most critical component to appetite control in the brain) was lower in fasting than in freely feeding mice [2].

Two recent studies have now provided some 'corner' pieces to the FTO puzzle. Church et al. [3] have created and characterized a mouse model that most closely resembles the human phenotype and Sovio et al. [4] have performed the most comprehensive assessment of how the association of FTO with BMI changes throughout childhood (as it must given the lack of association at birth and strong association by age 7 years).

\section{Association between variation in the FTO gene and BMI-related traits in childhood}

Children's weight corrected for their height follows a distinct pattern, peaking at around the age of 9 months to 1 year - the adiposity peak - and reaching a trough at approximately 5 years of age - the adiposity rebound before increasing again steadily before puberty (Figure 1). The recent study from Sovio et al. [4] provides compelling evidence that the minor allele in FTO (called the 'fat' allele) is associated with children emerging from their adiposity trough earlier than the major 'thin' allele. They also show, consistent with the original findings, that the minor allele is associated with increased BMI by the age of 7 years [4]. The earlier adiposity rebound was consistent across six studies (cited in [4]) that had measured children repeatedly between birth and puberty. Intriguingly, the same study [4] reported an inverse association at adiposity peak - the minor 'fat' allele was associated with lower BMI than the major 'thin' allele, not higher BMI as would be expected - although the statistical confidence of this finding was much less than the association with adiposity rebound.

\section{Maturation}

A recent genome-wide association study showed that the minor FTO 'fat' allele was associated with earlier sexual maturation in girls - the allele was associated with an average 0.5 months earlier age at menarche [5]. This finding was expected given the well known correlation between increased adiposity and earlier age at puberty in girls. The expectation is that an effect with puberty will 


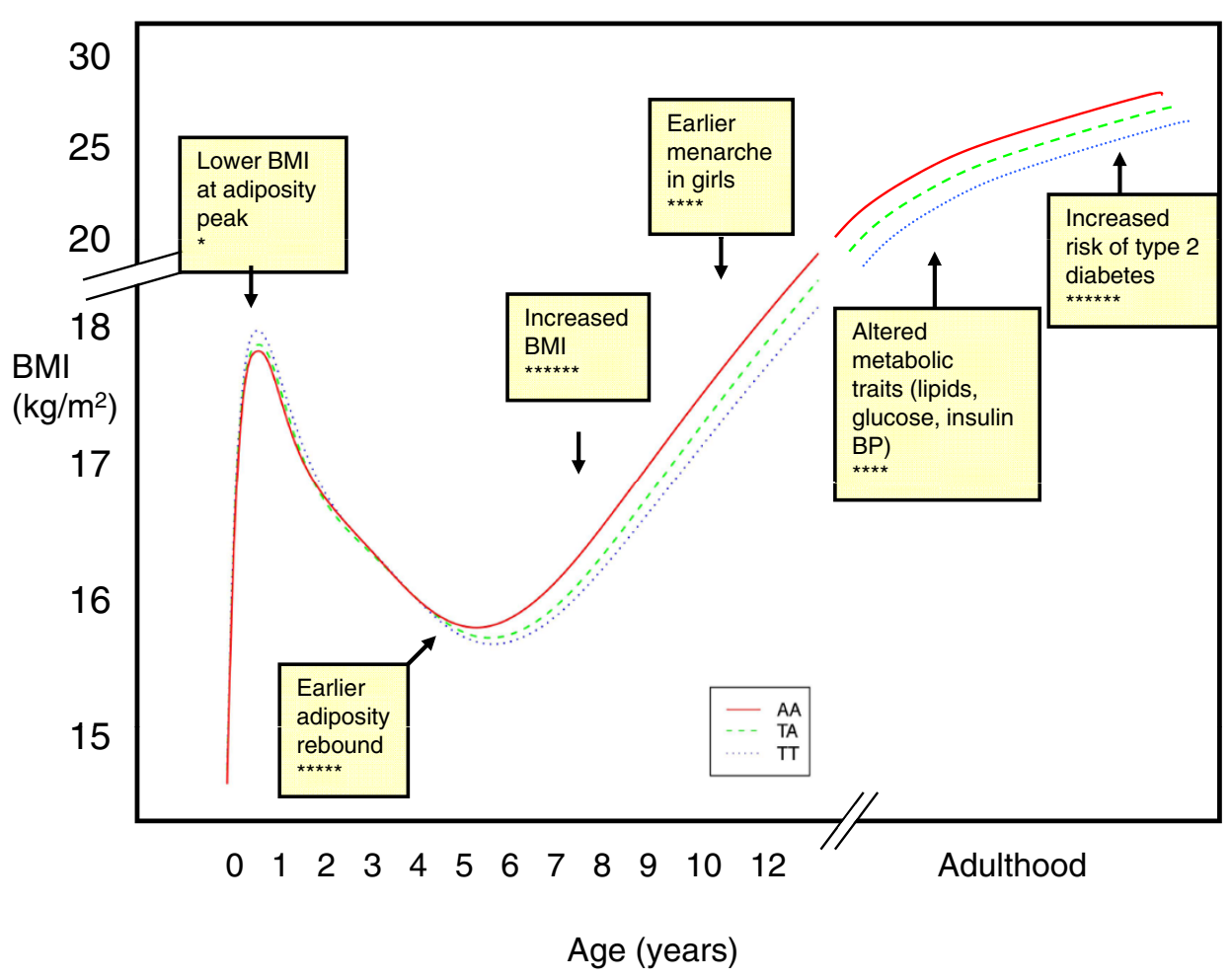

Figure 1. BMI throughout childhood and adulthood in individuals of different FTO genotypes. The A allele genotype is the minor 'fat' allele AT rs9939609. The figure was adapted from Sovio et al. [4] and is based on real association data in childhood and a schematic of the association in adulthood (BP, blood pressure). Boxes describe associations with the minor 'fat' allele and stars are indicative of the statistical confidence of the association.

also be seen in boys, although the effect may not be as strong given the weaker correlation between adiposity and puberty in boys.

\section{Appetite, activity or metabolism?}

Assessing the mechanism by which variants in the FTO gene influence adiposity is extremely challenging. The full effects of the variant are present by age 7 years in humans and by equivalent stages of maturity in mice. This immediately makes it very difficult to study the effects on appetite, activity, or metabolism because fatter individuals will eat, behave, and metabolize differently from the way thinner individuals do simply as a consequence of being more overweight. Human studies assessing the association between FTO alleles and appetite tried to overcome this problem by correcting statistics for BMI, but were still hindered by the well known phenomenon that overweight individuals tend to under-report what they eat.

Church et al. [3] tested a wide range of measures in mice with extra copies of the FTO gene and corrected their statistical associations for any differences in BMI. A picture emerged that mice with three or four copies of the FTO gene eat more for their body weight than mice with two copies of the gene. This energy intake effect predominated over alterations in metabolism and activity, which confirmed that the 'fat allele' phenotype was related to gain of function of FTO. Previous studies in mice showed that whole-body knockout or a dominant mutation in FTO resulted in thinner, smaller mice [6,7]. The predominant phenotype in these 'loss of function' models seemed to be faster metabolism, so further work in animal models is needed.

There is another important piece of the FTO jigsaw missing. If geneticists could identify a human FTO mutation that resulted in a severe obesity-related phenotype, it could provide a fundamental part of the picture. Such patients and their relatives could be studied in detail to elucidate the underlying mechanisms. Two studies have tried to identify individuals with rarer, more penetrant $F T O$ alleles. One [8] identified a mutation so severe that it resulted in an autosomal recessive lethal disorder with multiple defects, including severe postnatal growth retardation and a maximum survival of 2.5 years. The second [9] sequenced lean and obese individuals and identified several rare variants that resulted in some in vitro functional defects to the protein. However, the study [9] did not conclusively establish causality through 
co-segregation, and variants occurred in obese as well as lean individuals. It remains highly plausible that nature has provided scientists with a more relevant FTO monogenic phenotype to study, but the patients remain to be found.

In summary, there is still much to learn about the FTO gene and its product, but the pieces are starting to come together. None of these fascinating biological studies would have been possible without the initial genomewide association studies [1].

\section{Author details}

'Peninsula College of Medicine and Dentistry, University of Exeter, Magdalen Road, Exeter EX1 2LU, UK. ${ }^{2}$ MRC Epidemiology Unit, Institute of Metabolic Science, Addenbrookes Hospital, Cambridge CB2 0QQ, UK. ${ }^{3}$ MRC Unit for Lifelong Health and Ageing, 33 Bedford Place, London WC1B 5JU, UK

\section{Published: 24 February 2011}

\section{References}

1. Frayling, TM, Timpson, NJ, Weedon, MN, Zeggini, E, Freathy, RM, Lindgren, CM, Perry, JR, Elliott, KS, Lango, H, Rayner, NW, Shields, B, Harries, LW, Barrett, JC, Ellard, S, Groves, CJ, Knight, B, Patch, AM, Ness, AR, Ebrahim, S, Lawlor, DA, Ring, SM, Ben-Shlomo, Y, Jarvelin, MR, Sovio, U, Bennett, AJ, Melzer, D, Ferrucci, L, Loos, RJ, Barroso, I, Wareham, NJ, et al:: A common variant in the FTO gene is associated with body mass index and predisposes to childhood and adult obesity. Science 2007, 316:889-894.

2. Gerken T, Girard CA, Tung YC, Webby CJ, Saudek V, Hewitson KS, Yeo GS, McDonough MA, Cunliffe S, McNeill LA, Galvanovskis J, Rorsman P, Robins P, Prieur X, Coll AP, Ma M, Jovanovic Z, Faroogi IS, Sedgwick B, Barroso I, Lindah T, Ponting CP, Ashcroft FM, O'Rahilly S, Schofield CJ: The obesity-associated FTO gene encodes a 2-oxoglutarate-dependent nucleic acid demethylase. Science 2007, 318:469-472.

3. Church C, Moir L, McMurray F, Girard C, Banks GT, Teboul L, Wells S, Brüning JC, Nolan PM, Ashcroft FM, Cox RD: Overexpression of Fto leads to increased food intake and results in obesity. Nat Genet 2010, 42:1086-1092.
4. Sovio U, Mook-Kanamori DO, Warrington NM, Lawrence R, Briollais L, Palmer CNA, Cecil J, Sandling JK, Syvänen A, Kaakinen M, Beilin LJ, Millwood IY, Bennett AJ, Laitinenn J, Pouta A, Molitor J, Davey Smith G, Ben-Shlomo Y, Jaddoe VWV, Palmer LJ, Pennell CE, Cole TJ, McCarthy MI, Järvelin M, Timpson $\mathrm{NJ}$ and the Early Growth Genetics Consortium: Association between common variation at the FTO locus and changes in body mass index from infancy to late childhood: the complex nature of genetic association through growth and development PLOS Genet 2011, 7: e1001307

5. Elks CE, Perry JR, Sulem P, Chasman DI, Franceschini N, He C, Lunetta KL, Visser JA, Byrne EM, Cousminer DL, Gudbjartsson DF, Esko T, Feenstra B, Hottenga JJ, Koller DL, Kutalik Z, Lin P, Mangino M, Marongiu M, McArdle PF, Smith AV, Stolk L, van Wingerden SH, Zhao JH, Albrecht E, Corre T, Ingelsson E, Hayward C, Magnusson PK, Smith EN, et al. Thirty new loci for age at menarche identified by a meta-analysis of genome-wide association studies. Nat Genet 2010, 42:1077-1085.

6. Church C, Lee S, Bagg EA, McTaggart JS, Deacon R, Gerken T, Lee A, Moir L, Mecinović J, Quwailid MM, Schofield CJ, Ashcroft FM, Cox RD: A mouse model for the metabolic effects of the human fat mass and obesity associated FTO gene. PLoS Genet 2009, 5:e1000599.

7. Fischer J, Koch L, Emmerling C, Vierkotten J, Peters T, Brüning JC, Rüther U Inactivation of the Fto gene protects from obesity. Nature 2009, 458:894-898.

8. Boissel S, Reish O, Proulx K, Kawagoe-Takaki H, Sedgwick B, Yeo GS, Meyre D, Golzio C, Molinari F, Kadhom N, Etchevers HC, Saudek V, Faroogi IS, Froguel P, Lindahl T, O'Rahilly S, Munnich A, Colleaux L: Loss-of-function mutation in the dioxygenase-encoding FTO gene causes severe growth retardation and multiple malformations. Am J Hum Genet 2009, 85:106-111.

9. Meyre D, Proulx K, Kawagoe-Takaki H, Vatin V, Gutiérrez-Aguilar R, Lyon D, Ma M, Choquet H, Horber F, Van Hul W, Van Gaal L, Balkau B, Visvikis-Siest S, Pattou F, Farooqi IS, Saudek V, O'Rahilly S, Froguel P, Sedgwick B, Yeo GS: Prevalence of loss-of-function FTO mutations in lean and obese individuals. Diabetes 2009, 59:311-318.

doi:10.1186/gb-2010-12-2-104

Cite this article as: Frayling TM, Ong K: Piecing together the FTO jigsaw.

Genome Biology 2011, 12:104. 